\title{
FILM ANIMASI SEBAGAI MEDIUM DOKUMENTASI KEKAYAAN ALAM, INTELEKTUAL, BUDAYA, DAN DINAMIKA SOSIAL POLITIK
}

\author{
Ardiyansah \\ Jurusan Desain Komunikasi Visual, School of Design, BINUS University \\ Jln. K.H. Syahdan No 9, Kemanggisan, Jakarta Barat 11480 \\ sah@binus.ac.id
}

\begin{abstract}
Animation is a medium that has the ability to represent a visual phenomenon as a whole. Animation is not just a work of image-driven, but the work depicted motion, as expressed by Norman McLaren, Canadian animator Academy Award winner. As the interpretation of the motion, the animation is not subject to the laws of nature, so there is no limitation including movements that cannot be done in the real world or recorded in the live-action movie. So is the characterization or characterizations in the animation can be so free and open more opportunities for exploration. This advantage makes the animation a favorite medium to draw the attention of the audience, especially in the growing era of digital animation technology. Animation is now not only used for entertainment purposes, but has penetrated other fields such as education, tourism, health care, and so on. As a cultural product, animation, as well as films and works of art of human culture in general, is a historical marker that describes the spirit of an era that functions inherent in the animated film documentation of socio-political dynamics of a nation in a given period. This paper describes the process of documentation of natural, intellectual, cultural and socio-political dynamics in countries that intensively utilize the medium of animation.
\end{abstract}

Keywords: animation, films, documentation, socio dynamic, political dynamic

\begin{abstract}
ABSTRAK
Animasi adalah medium yang memiliki kemampuan untuk menggambarkan suatu fenomena visual secara utuh. Animasi bukan sekedar karya gambar yang digerakkan, tetapi karya gerak yang digambarkan, seperti yang diungkapkan oleh Norman McLaren, animator asal Kanada pemenang Academy Award. Sebagai tafsir atas gerak, animasi tidak tunduk pada hukum alam, sehingga tidak ada batasan termasuk gerakangerakan yang tidak bisa dilakukan dalam dunia nyata atau direkam dalam film live-action. Begitu juga karakterisasi atau penokohan dalam animasi bisa sedemikian bebas dan membuka lebih banyak peluang untuk ber-eksplorasi. Kelebihan ini membuat animasi menjadi medium favorit untuk menarik perhatian khalayak terutama di era teknologi animasi digital yang semakin berkembang. Animasi kini tidak hanya digunakan untuk hiburan semata, tetapi telah merambah bidang-bidang lain seperti pendidikan, pariwisata, kesehatan, dan sebagainya. Sebagai produk budaya, animasi seperti halnya film dan karya seni budaya manusia secara umum, merupakan penanda sejarah yang menggambarkan semangat suatu jaman sehingga dalam film animasi melekat fungsi dokumentasi atas dinamika sosial politik suatu bangsa pada suatu kurun tertentu. Tulisan ini memaparkan proses dokumentasi kekayaan alam, intelektual, budaya dan dinamika sosial politik di beberapa negara yang secara intensif memanfaatkan medium animasi.
\end{abstract}

Kata kunci: animasi, film, dokumentasi, dinamika sosial, dinamika politik 


\section{PENDAHULUAN}

Animasi adalah medium serbaguna yang dapat digunakan untuk menggambarkan apapun yang terbersit dalam pikiran manusia. Hal ini yang kurang lebih disampaikan oleh Walt Disney dalam salah satu kutipannya yang terkenal. Disney percaya dengan berbagai kekuatan dan kelebihannya, animasi memiliki kemampuan untuk mewujudkan gagasan secara lebih gamblang, tanpa batas, dan mampu diapresiasi oleh khalayak secara lebih luas. Gagasan ini kurang lebih merupakan tafsir atas pernyataan Walt Disney, "Animation can explain whatever the mind of man can conceive. This facility makes it the most versatile and explicit means of communication yet devised for quick mass appreciation."

Pernyataan Walt Disney tersebut di atas menegaskan bahwa animasi dapat dimanfaatkan untuk berbagai kebutuhan. Animasi bisa dikembangkan sebagai hiburan, tetapi menyimpan potensi untuk dioptimalkan pada bidang-bidang lain yang membutuhkan medium komunikasi yang berkaitan dengan transfer pesan dan gagasan. Prakosa (2010) menyebutkan setidaknya ada 10 fungsi animasi yang meliputi: (1) membuka tabir yang tidak nyata (relevation of invisible forces); (2) menggambarkan berbagai proses (depiction of processes); (3) menyederhanakan berbagai proses (simplification of processes); (4) membuat peka terhadap subjeknya (desensitization of subject matter); (5) berkreasi dalam bentuk visual secara utuh (creation of visual generalizations and projections); (6) rekreasi ke masa lalu (recreation of the past); (7) presentasi elemen yang selalu berhubungan (progressive presentation of related elements); (8) persembahan isyarat visual (offering visual cues); (9) animasi mengungkap analogi visual (animation of visual analogies); (10) memperkokoh ide untuk membentuk karakter (giving character to ideas).

Pemaparan Prakosa mengenai fungsi animasi tersebut memberikan kita gambaran bahwa animasi lebih dari sekedar membuat film kartun, tetapi lebih dari itu animasi dapat dipakai untuk menyampaikan informasi, pesan, gagasan, dan bahkan yang bersifat propaganda untuk berbagai tujuan dan kepentingan. Contoh sederhana adalah penggunaan animasi sebagai medium ajar. Animasi dianggap mampu menjelaskan proses imiah dan yang berkaitan dengan urutan kejadian secara lebih gamblang dan detail, sehingga kekuatan ini terus dikembangkan dalam dunia pendidikan baik dalam format pembelajaran linier maupun interaktif.

Selain dikembangkan sebagai film untuk hiburan dan medium ajar, salah satu fungsi animasi yang melekat adalah sebagai medium dokumentasi. Sering kali tidak disadari, hal ini (dokumentasi) berkaitan dengan bagaimana film animasi mengangkat tema tertentu seperti kekayaan alam, budaya, intelektual, dan lain-lain yang menjadi penanda sejarah suatu masyarakat atau bangsa dalam kurun waktu tertentu. Hal ini secara implisit maupun terang-terangan telah dilakukan oleh banyak negara seperti Amerika, Jepang, dan yang terbaru adalah Malaysia. Saat ini Malaysia berusaha mewujudkan ambisi besarnya menjadi pusat rujukan peradaban Melayu dan Asia (Tenggara) dengan memanfaatkan kemajuan ICT (Information \& Communication Technology) dengan diprakarsai oleh MDEC (Multimedia Development Corporation), sebuah lembaga pemerintahan yang berwenang atas promosi dan pengembangan produk industri ICT di Malaysia.

MDEC memberikan dukungan kepada kelompok-kelompok usaha di bidang ICT (termasuk animasi) untuk berkarya dengan mengangkat tema budaya lokal. Semua ini dilakukan untuk mendukung ambisi pemerintahan Malaysia menjadi pusat peradaban Melayu dan Asia Tenggara. Sayangnya, Malaysia tak cukup puas dengan kekayaan yang mereka miliki, bahkan kini menjadi sangat ekspansif dan justru banyak membuat film animasi yang mengangkat tema budaya yang berasal dari negara lain termasuk Indonesia seperti dongeng Timun Mas, Bawang Merah Bawang Putih, Kerajaan Nusantara dan lain-lain untuk mendukung propaganda tersebut. 


\section{METODE PENELITIAN}

Penelitian dilakukan dengan melakukan studi literatur dari berbagai sumber baik berupa buku, jurnal, kumpulan jurnal, penelitian ilmiah, film, sumber-sumber terpercaya di internet dan lain-lain yang relevan untuk mendapatkan data-data dan informasi yang diperlukan. Selain itu, penulis juga melakukan studi berbasis praktik dengan eksplorasi metode storytelling, strategi komunikasi, dan desain karakter.

\section{HASIL DAN PEMBAHASAN}

Tafsir tentang gerak telah dimulai sejak masa prasejarah, di mana manusia yang ketika itu banyak bermukim di gua telah berusaha menggambarkan objek-objek di sekitarnya (terutama binatang) dengan memberikan kesan hidup, gambar atau lukisan binatang yang terdapat di gua-gua prasejarah memiliki jumlah kaki lebih banyak dari semestinya, fenomena yang sering dianggap sebagai upaya untuk memberikan kesan hidup atau bergerak. Usaha manusia menafsir gerak tersebut masih dapat dilihat pada gua-gua purba seperti Lascaux (Pransis), Altamira (Spanyol), dan Leangleang (Maros, Sulawesi Selatan, Indonesia).

Animasi sebagaimana produk peradaban lainnya terus berkembang menyesuaikan dinamika zaman. Dari sebelumnya diproduksi untuk kepentingan hiburan, animasi kini berkembang dan merambah ke lebih banyak aspek kehidupan manusia untuk menjelaskan fenomena-fenomena seperti: pendidikan, sosial, kebudayaan, politik, sejarah, dan lain-lain yang berkaitan dengan informasi yang lebih eksplisit, gamblang, dan tanpa batas.

Seperti halnya film, animasi juga berfungsi untuk menyampaikan gagasan tertentu sekaligus sebagai penanda sejarah. Artinya ketika film atau animasi ditonton, maka dapat memberikan gambaran mengenai kondisi dan semangat zaman ketika karya tersebut diproduksi. Dan hal ini kurang lebih relevan dengan fungsi yang dipaparkan Gotot Prakosa bahwa animasi berfungsi sebagai medium rekreasi ke masa lalu, walaupun mungkin lebih tepat jika dikatakan sebagai medium rekreasi dari masa ke masa. Karena sifat animasi yang eksplisit dan tidak terbatas, film animasi dapat memberikan penggambaran dari masa lalu, sekarang, dan masa yang akan datang.

Sebagai medium dokumentasi, animasi sangat erat kaitannya dalam upaya membangun citra tertentu yang dikehendaki oleh kekuatan yang menjadi inisiator produksi animasi tersebut. Beberapa hal yang biasanya menjadi tujuan dibuatnya film animasi berdasarkan kegunaannya adalah sebagai berikut: (1) komersial: dalam konteks industri dan bisnis, film animasi tidak bisa lepas dari kepentingan komersial, animasi dibuat dengan tujuan mendapatkan keuntungan baik secara langsung dari penjualan film, maupun dari produk-produk derivatif yang potensinya juga tidak bisa dianggap sebelah mata; (2) hiburan: fungsi animasi sebagai hiburan dapat kita lihat pada film kartun dan sejenisnya; (3) propaganda dan pencitraan: propaganda dalam animasi (dan secara umum dalam film) biasanya terselip dengan sangat implisit terkait kepentingan atau ideologi suatu negara baik yang ditujukan ke luar maupun ke dalam. Amerika dulu membuat animasi bertema superhero untuk membangkitkan semangat warganya agar melepaskan diri dari keterpurukan akibat kerugian dan kesedihan mendalam yang diderita akibat peperangan. Suatu unsur propaganda berupa karakter yang kuat tak terkalahkan dimasukkan agar seluruh orang Amerika percaya bahwa mereka adalah orangorang yang hebat. Belakangan, propaganda tersebut dibawa keluar untuk membangun citra bahwa Amerika memang negeri para pahlawan, negeri adidaya yang superior. Hampir mirip seperti propaganda, pencitraan adalah upaya persuasif yang lebih ditujukan untuk kepentingan yang lebih kecil, bisa individu maupun kelompok. (4) Publikasi dan promosi: film animasi juga dapat digunakan 
untuk mempromosikan suatu produk, event, aset pariwisata, dan lain-lain. Animasi menawarkan kemudahan dalam penyampaian gagasan sehingga penceritaan tidak selalu linier dan dapat menarik perhatian; 5) Pendidikan: Fungsi animasi sebagai pendidikan sangat erat kaitannya dengan konten. Sebuah film animasi pendidikan biasanya mengedepankan muatan isi yang informatif dan edukatif. Umumnya, animasi edukasi bersifat kaku karena sangat terbatas oleh konten yang ingin diangkat, tetapi produk animasi terbaru saat ini berusaha menggabungkan animasi sebagai media pendidikan tetapi tetap bersifat menghibur.

\section{Animasi dan Dinamika Sosial Politik Suatu Bangsa}

Tinarbuko (2008) sempat menyinggung bahwa karya desain komunikasi visual (termasuk animasi dan new media) merupakan saksi sejarah atas perkembangan dinamika sosial politik bangsa Indonesia. Pernyataan ini merupakan penegasan bahwa tiap-tiap produk budaya memiliki peran sebagai saksi dan penanda sejarah yang bisa bercerita mengenai kondisi suatu bangsa pada suatu kurun tertentu. Dalam konteks film animasi, kita melihat bahwa suatu karya tak lepas dari kepentingan dokumentasi karena sejatinya bersifat inheren. Dokumentasi yang dimaksud penulis bisa berupa kondisi alam, kebudayaan, kekayaan intelektual serta dinamika sosial dan politik.

\section{Malaysia}

Contoh paling gamblang pemanfaatan animasi sebagai dokumentasi adalah apa yang saat ini dilakukan oleh Malaysia. Dengan ambisinya untuk menjadi pusat peradaban Melayu dan Asia Tenggara, Malaysia saat ini memberikan prioritas untuk mengembangkan animasi melalui MDEC (Multimedia Development Corporation), lembaga yang berwenang atas perkembangan industri ICT (Information \& Communication Technology) di Malaysia dan telah menjadi inisiator film-film animasi Malaysia yang memuat kekayaan lokal seperti Upin dan Ipin, Bo Boi Boy, Saladin, dan lain-lain. Memerhatikan film-film animasi Malaysia, sebenarnya tidak semuanya sukses secara komersial. Akan tetapi, keberhasilan menembus jaringan televisi nasional Indonesia dan global merupakan pukulan tersendiri bagi pegiat animasi nasional yang semakin tidak mendapatkan tempat di rumahnya sendiri. Animasi nasional lebih banyak diapresiasi pada lomba-lomba, seminar, short movie, proyek outsource dari luar negeri dan proyek pemerintahan. Hingga saat ini animasi nasional belum berhasil menjadi ikon yang berhasil menjadi tuan rumah di negeri sendiri. Sementara itu, akibat dorongan dan stimulus yang diberikan oleh pemerintah, pegiat animasi di Malaysia juga seperti berlomba-lomba membuat film animasi seperti Timun Mas, Nusantara Fantasy, Bawang Putih - Bawang Merah, dan mungkin lebih banyak lagi tema-tema yang sebenarnya berasal dari Indonesia dan negara-negara lain. Hal ini menjadi menarik dan patut dicermati karena dokumentasi yang dibuat oleh Malaysia cenderung menjadi bagian dari propaganda Malaysia sebagai pusat peradaban Melayu dan Asia (Tenggara) seperti yang dinyatakan dalam slogan pariwisata mereka: "Truly Asia.”

Salah satu film animasi paling fenomenal dari Malaysia di Indonesia. Banyak mengangkat kearifan lokal, termasuk dalamnya tradisi hari raya, permainan tradisional, ziarah kubur, dan kekayaan kuliner termasuk tempe. Saat ini secara regular juga telah memasukkan karakter dari Indonesia bernama Susanti.

Animasi Malaysia yang bercerita tentang sekelompok anak jagoan yang melawan invasi makhluk asing. Salah satu karakter utamanya mengenakan jilbab sementara komposisi karakter masih perpaduan 3 (tiga) etnis utama Malaysia yaitu Melayu, Cina, dan India. Formula serupa yang diterapkan di Upin dan Ipin. 


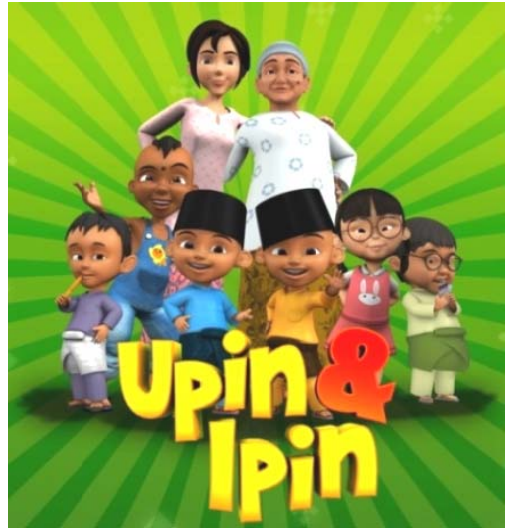

Gambar 1 Upin \& Ipin

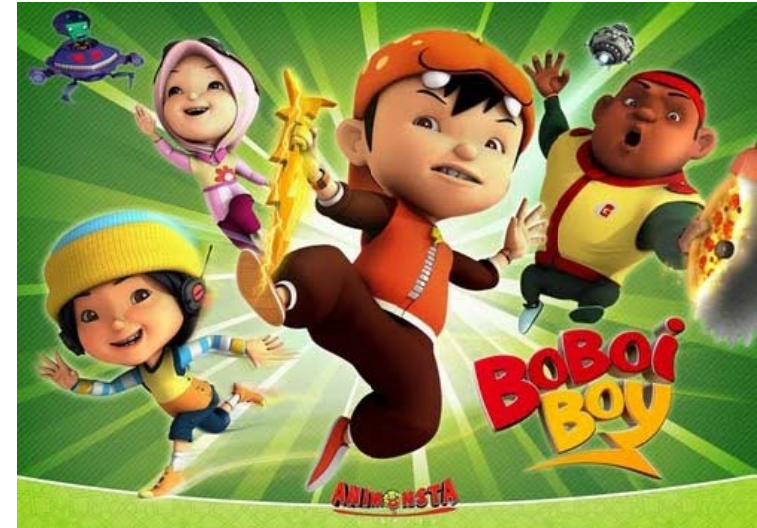

Gambar 2 Boboi Boy

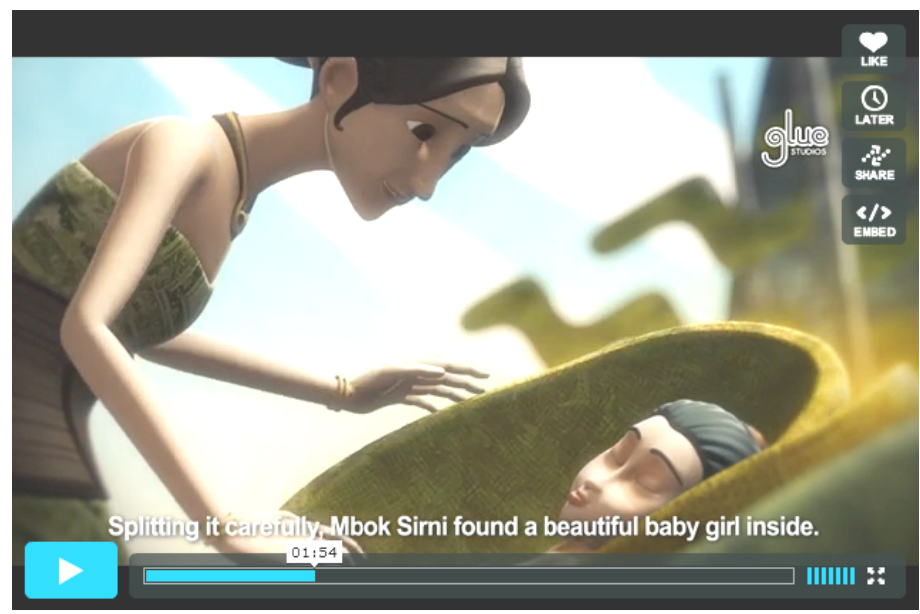

Gambar 3 Timun Mas

Dongeng asli Indonesia ini diadopsi menjadi animasi oleh sebuah studio di Malaysia. Meskipun cerita ini berasal dari Jawa, tetapi lagu iringannya menggunakan musik khas Sunda. Sebuah interpretasi yang menggambarkan kedangkalan dalam memahami kekayaan budaya asli dongeng ini berasal, yaitu Indonesia. Selain Timun Mas, studio yang sama juga menggarap Bawang Merah dan Bawang Putih.

Animasi karya mahasiswa Malaysia ini banyak terinspirasi dari kekayaan budaya Melayu yang tersebar di Malaysia dan Indonesia. Penggunaan nama "Nusantara" sendiri adalah pilihan yang merujuk pada gugusan kepulauan di Indonesia. Sementara keris dan langgam tradisional merupakan interpretasi atas kebudayaan Melayu di Malaysia dan Indonesia.

\section{Jepang}

Jepang pada awalnya memanfaatkan animasi untuk merekonstruksi semangat nasionalisme yang ambruk akibat kalah perang. Film animasi generasi pertama yang diproduksi oleh Jepang banyak bercerita tentang kepahlawanan dan tema-tema politik. Bedanya dengan buatan Amerika, karakter pahlawan film animasi bersifat inklusif, artinya siapapun bahkan tokoh yang paling tak terduga sekalipun bisa menjadi pahlawan dalam film animasi Jepang. Tidak harus superhero berbadan besar seperti penggambaran film animasi Amerika pada umumnya. 


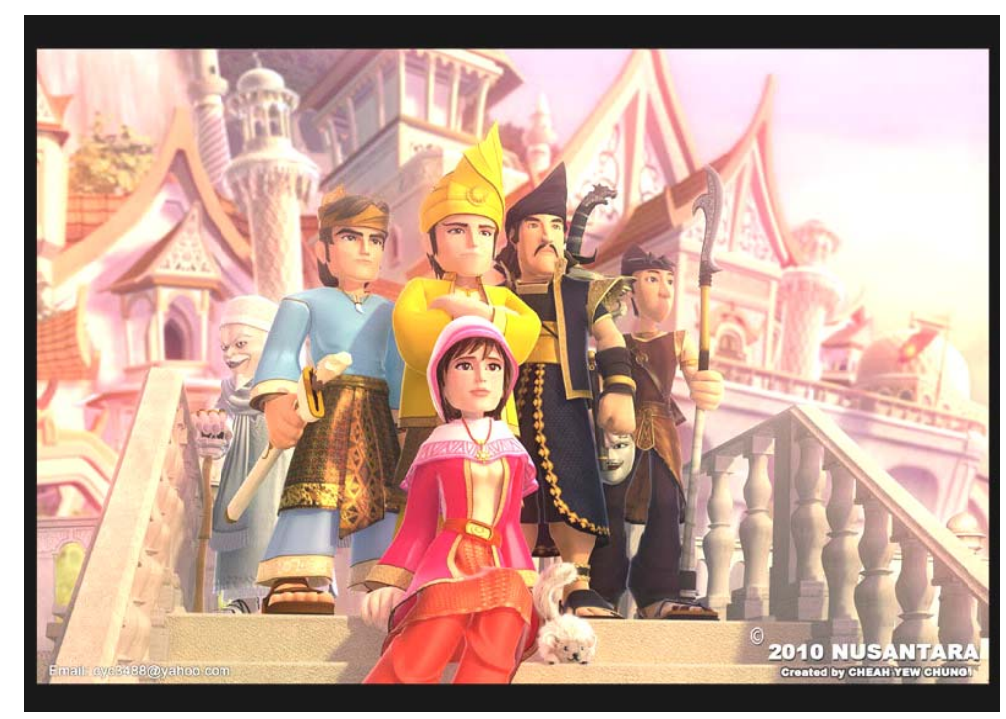

Gambar 4 Nusantara

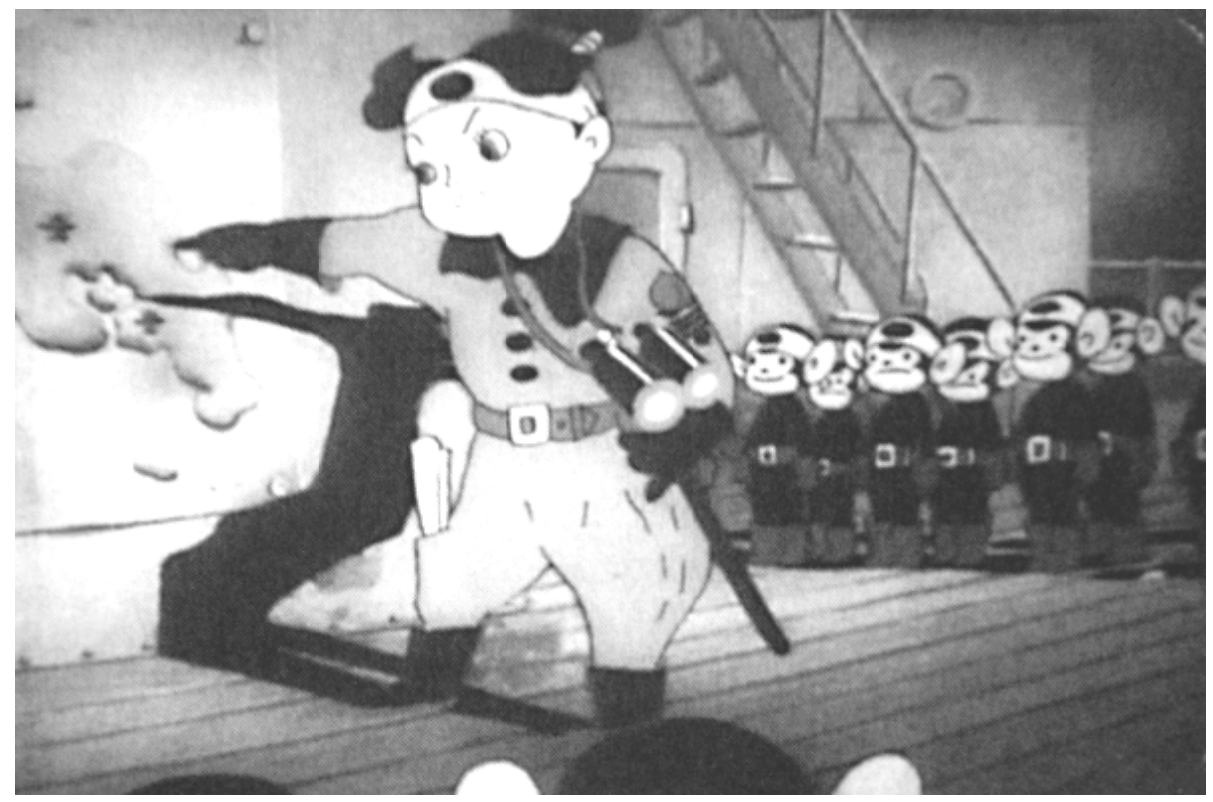

Gambar 5 Momotaro’s Sea Eagle

Dianggap sebagai film animasi klasik Jepang generasi pertama yang sekaligus menjadi bagian propaganda Angkatan Laut Jepang. Salah satu animasi Jepang yang banyak mengangkat kekayaan lokal berupa cerita-cerita rakyat terutama yang berkaitan dengan mitos makhluk ghaib dari dunia lain. Diceritakan dengan gaya eklektik dari sudut pandang seorang anak masa kini yang terjebak dalam dunia khayal tersebut. Salah satu animasi Jepang yang digandrungi saat ini. Banyak memasukkan kearifan lokal yang bersumber pada cerita tentang Ninja dan patriotisme masyarakat Jepang. 


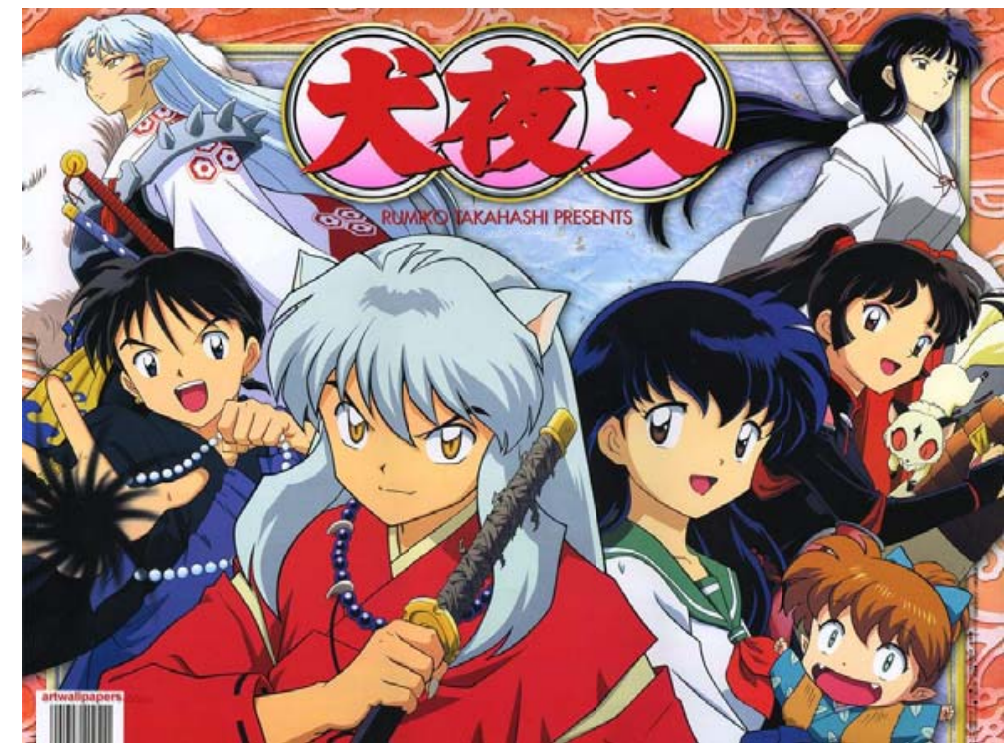

Gambar 6 Inuyasha

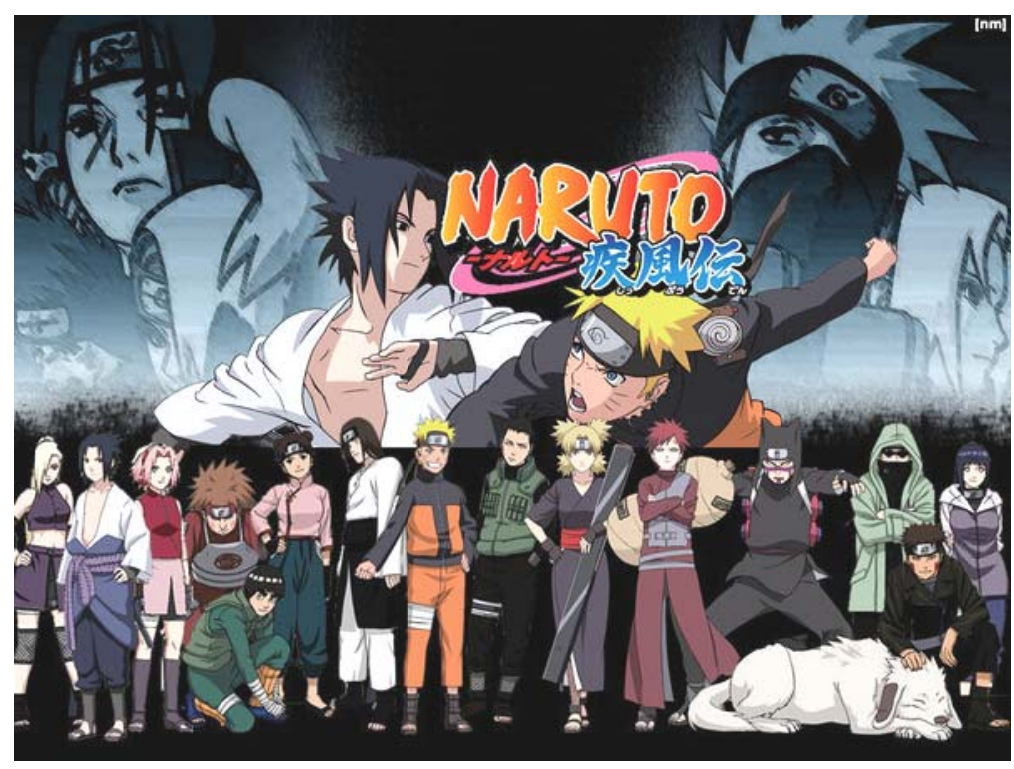

Gambar 7 Naruto

\section{Amerika}

Film animasi Amerika generasi awal lebih banyak mengeksplorasi gerak dan lebih banyak ditujukan untuk kepentingan hiburan. Memasuki Golden Age di mana televisi menjadi sangat dominan, animasi berkembang menjadi industri serius. Terlebih ketika animasi kemudian berkolaborasi dengan komik yang lebih dulu berkembang sehingga memunculkan karakter-karakter superhero yang kemudian menjadi ciri khas animasi Amerika.

Animasi Amerika memang tidak bisa lepas dari sosok Walt Disney. Persistensi dan dedikasinya membuat animasi di Amerika berkembang menjadi bisnis yang besar. Steamboat Willie adalah animasi berorientasi komersial generasi pertama di Amerika. 


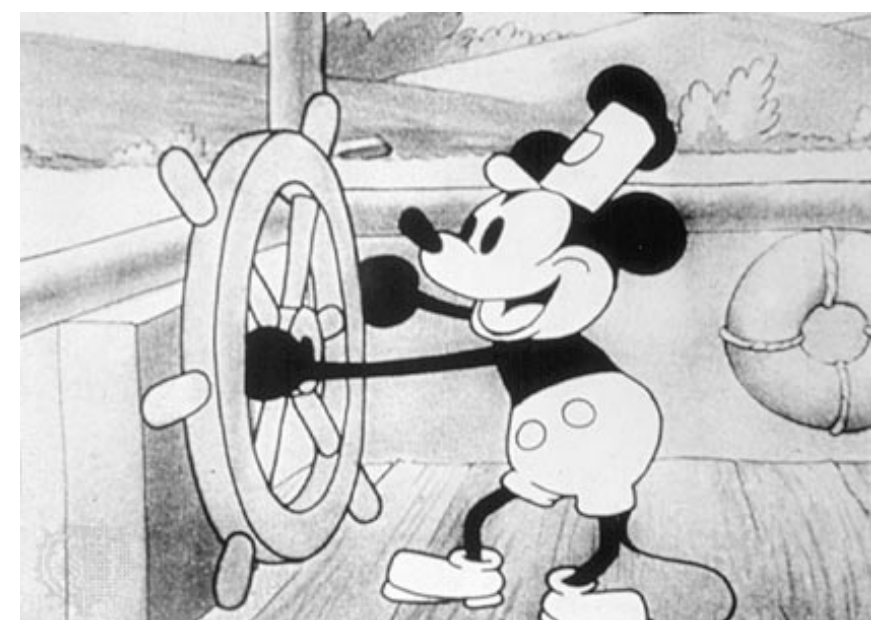

Gambar 8 Mickey Mouse dalam Steamboat Willie

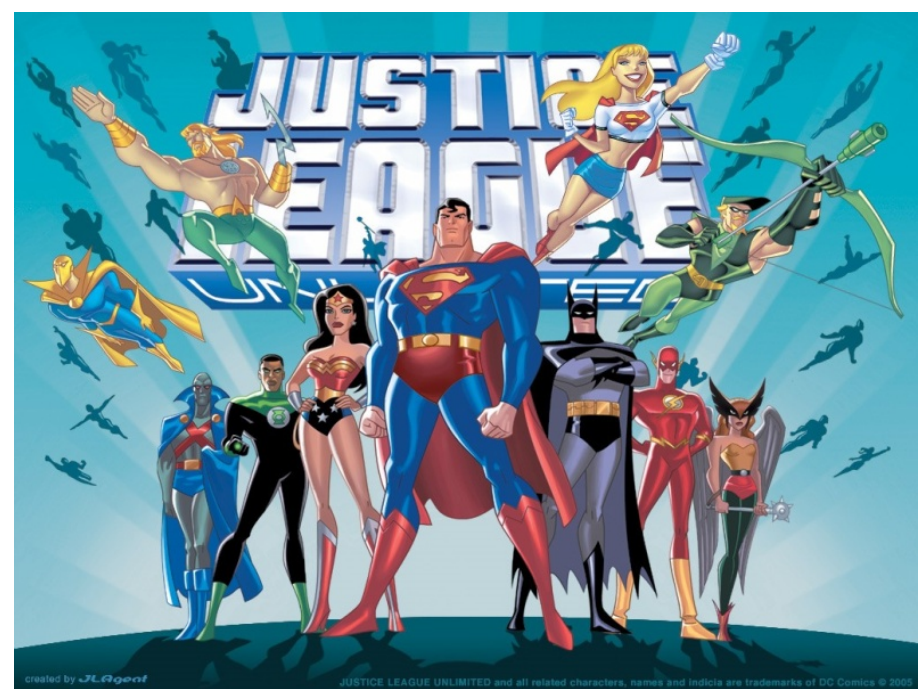

Gambar 9 Justice League

Pada masa ini superhero menjadi tren dalam industri animasi, karakter-karakter manusia super dieksploitasi sehingga jumlah dan variasinya sangat banyak. Propaganda yang mengesankan Amerika sebagai negeri para pahlawan banyak dimasukkan melalui animasi yang menggabungkan berbagai karakter superhero ini.

\section{Eropa}

Animasi Eropa berkembang terutama di Inggris dan Prancis. Bahkan Prancis tercatat sebagai negara pertama yang mengembangkan animasi kartun. Prancis juga menjadi negara yang menjadi inisiator diselenggarakannya event tahunan animasi (Annecy). Animasi ini merupakan alih media dari komik Herge (komikus Belgia yang bernama asli Georges Remi) yang terkenal di Eropa. Serial Animasi ini sebagian besar diilhami suasana Perang Dunia dan merupakan kerja sama banyak pihak meliputi studio animasi dari Prancis, Kanada, dan Belgia. Animasi berbasis CGI ini secara gamblang menceritakan sejarah Polandia dari masa ke masa. Fokusnya adalah pada permasalahan sosial, politik, dan militer yang sangat dominan dalam short movie berdurasi 8 menit ini. 


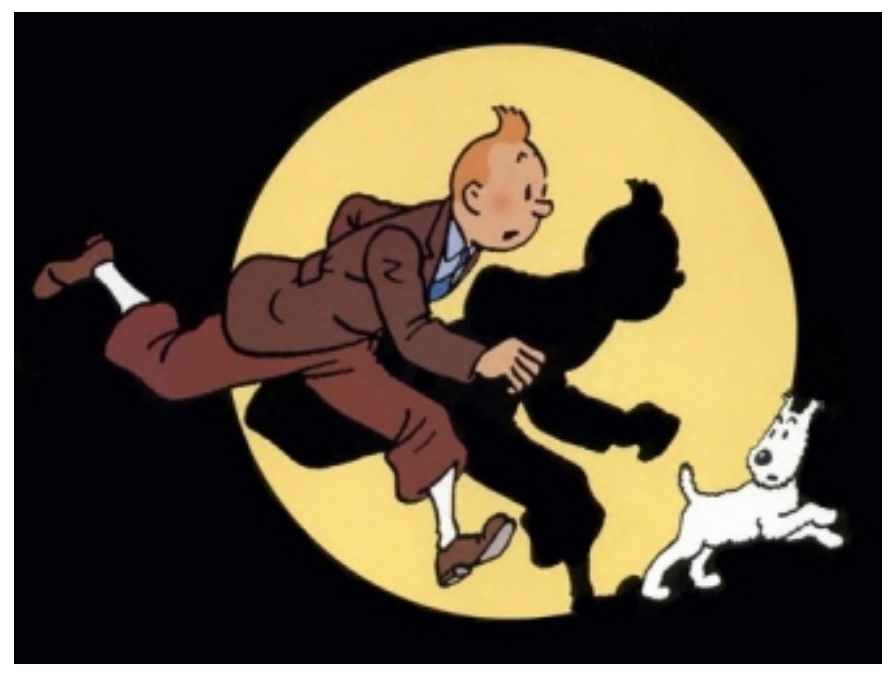

Gambar 10 Tintin TV Series.

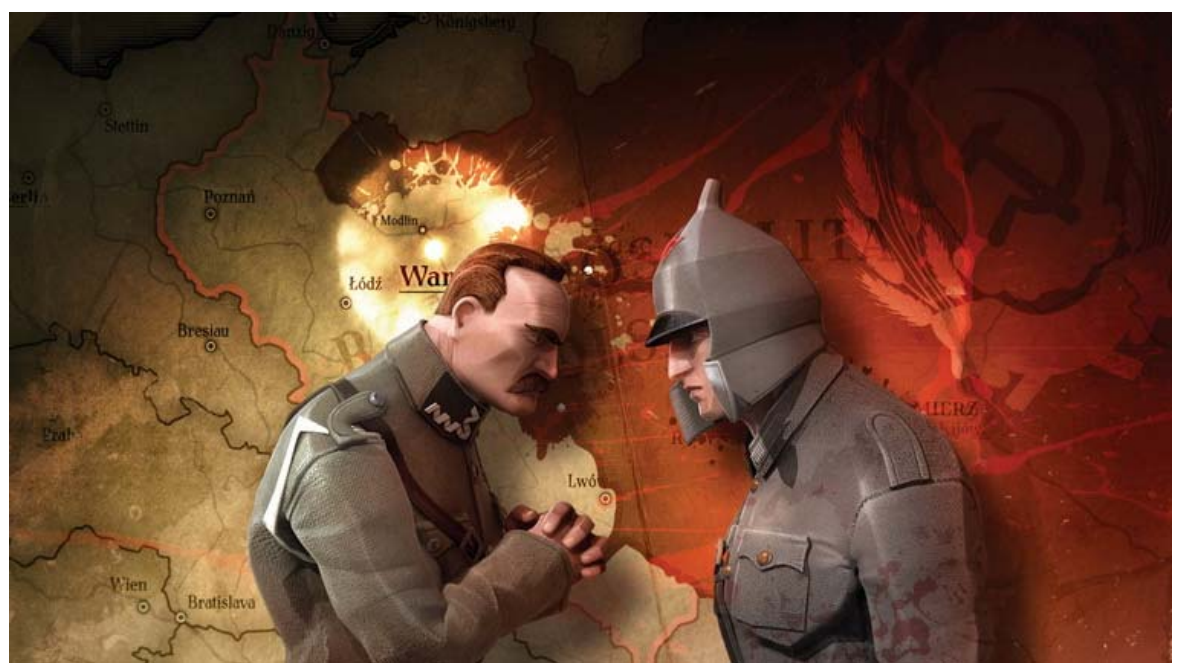

Gambar 11 History of Poland.

\section{Indonesia}

Meskipun animasi Indonesia masih harus berjuang mengejar ketertinggalan dari negara-negara lain, bukan berarti Indonesia miskin karya animasi. Banyak sekali animasi Indonesia yang turut menjalankan fungsi dokumentasi tersebut.

Animasi ambisisus ini bercerita tentang petualangan Jambul dan kawan-kawannya ke berbagai tempat di Indonesia. Dalam setiap episode Jambul mengangkat kekayaan alam, budaya, dan intelektual Indonesia seperti Barong, Ondel-ondel, dan Komodo. 


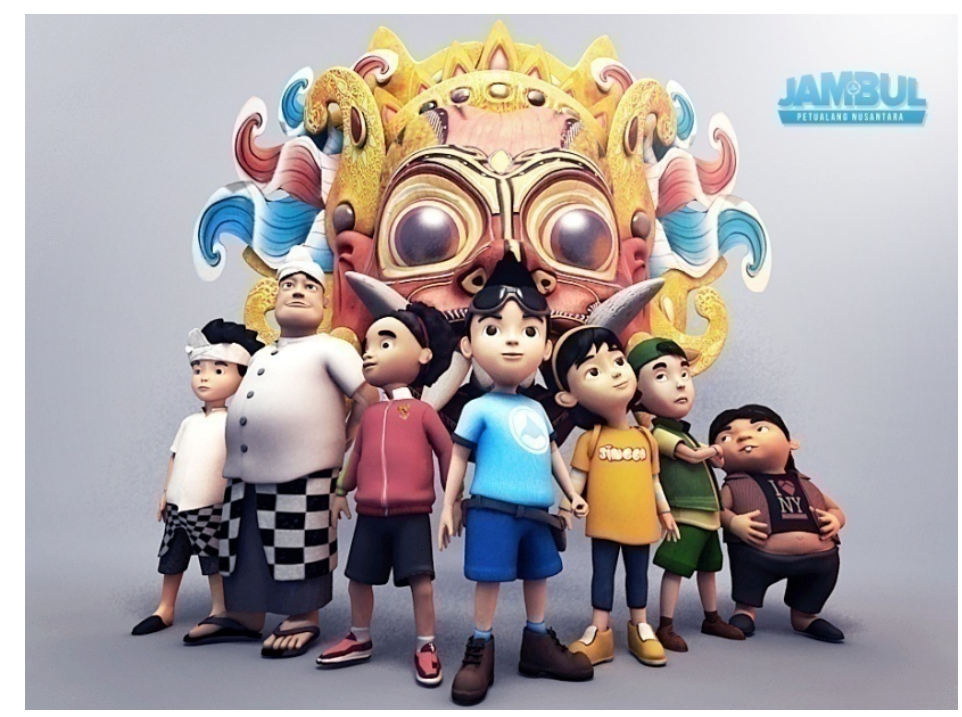

Gambar 12 Jambul: Petualang Nusantara

\section{SIMPULAN}

Animasi terus berkembang menjadi medium yang serbaguna seperti yang dulu pernah disampaikan oleh Walt Disney. Film animasi memiliki peran dan fungsi yang sama dengan film pada umumnya yaitu sebagai penanda jaman, medium dokumentasi dinamika sosial dari masa ke masa. Kita menyaksikan banyak negara yang lebih dahulu mencapai kemajuan telah memanfaatkan film animasi untuk berbagai kepentingan strategisnya. Amerika dengan propagandanya, Jepang dengan kepentingan industrinya, dan kini Malaysia dengan ambisinya untuk menjadi pusat peradaban Asia (Tenggara). Indonesia, yang walaupun bisa dikatakan belum memiliki tradisi animasi, tetapi sebenarnya telah merintis kemajuan melalui jalur lain seperti menjadi kekuatan produksi untuk kepentingan pihak luar. Barangkali sudah saatnya pegiat animasi nasional berfikir untuk mengoptimalkan peran film animasi sejajar dengan medium-medium lain sebagai dokumentasi dinamika sosial politik negeri ini. Peran yang serius dari industri yang masih dianggap sebelah mata oleh banyak kalangan di negeri ini.

\section{DAFTAR PUSTAKA}

Prakosa, G. (2010). Animasi: Dasar pengetahuan film animasi Indonesia. Jakarta: Fakultas Film dan Televisi, Institut Kesenian Jakarta \& Yayasan Seni Visual Indonesia.

Tinarbuko, S. (2008). Semiotika komunikasi visual. Yogyakarta: Jalasutra. 